\title{
Memperkokoh Keterkaitan Ketahanan Pangan, Energi, dan Air (Food-Energy-Water Nexus) da- lam Perencanaan Pembangunan Indonesia
}

\author{
Hanan Nugroho ${ }^{1}$
}

\section{Afiliasi}

${ }^{1}$ Perencana Ahli Utama di Direktorat Energi dan Sumber Daya Mineral Kementerian Perencanaan Pembangunan Nasional/Bappenas Republik Indonesia

Korespondensi: nugrohohn@bappenas.go.id

\begin{abstract}
Abstrak
Pangan, energi, dan air memiliki keterkaitan (nexus) yang kuat, termasuk dampaknya terhadap perubahan iklim dan pembangunan berkelanjutan. Perhatian terhadap keterkaitan ini semakin berkembang di dunia internasional. Rencana Pembangunan Jangka Menengah Nasional (RPJMN) 2020-2024 masih menerapkan perencanaan pembangunan ketahanan pangan, energi, dan air secara sendiri-sendiri, belum menekankan keterkaitan antar mereka. Makalah ini mengusulkan agar dilakukan kajian mengenai keterkaitan antara ketahanan pangan, ketahanan energi, dan ketahanan air serta mengembangkan kebijakan pembangunan mengenai keterkaitan tersebut untuk kasus Indonesia. Selanjutnya perencanaan pembangunan yang didasarkan pada keterkaitan antara ketiga sumber utama kehidupan tersebut (pangan, energi, air) dapat disusun dan secara eksplisit diperlihatkan dalam Rencana Kerja Pemerintah (RKP) tahun-tahun berikutnya dalam kurun RPJMN 2020-2024 dan ke depan.
\end{abstract}

Kata kunci: keterkaitan pangan, energi, air (FEW Nexus), RPJMN, perubahan iklim dan pembangunan berkelanjutan, perencanaan pembangunan

Doi: https://doi.org/10.47266/bwp.v3i2.80 | halaman: 238-243

Dikirim pada: 09 Agustus 2020. Diterima pada: 28 August 2020. Dipublikasikan pada: 07 September 2020 


\section{Pendahuluan}

Pangan, Energi, dan Air adalah kebutuhan dasar dan sumber kehidupan utama manusia. Seiring dengan pertambahan penduduk dan pertumbuhan ekonomi, kebutuhan akan pangan, energi dan air terus meningkat. Ini dialami oleh hampir seluruh negara di muka bumi. Pertumbuhan permintaan akan pangan, energi dan air yang tinggi, pemanfaatan mereka yang tidak efisien serta tidak diimbangi dengan ketersediaan sumber dayanya yang dapat dijangkau, telah menjadikan kelangkaan pangan, energi, dan air permasalahan kritis yang dihadapi banyak negara. Konflik memperebutkan pangan, energi dan air bahkan diperkirakan semakin banyak ke depan, seiring dengan pertumbuhan jumlah penduduk dan peningkatan kemakmuran yang disertai dengan peningkatan permintaan akan pangan, energi, dan air yang dibutuhkan untuk industrialisasi maupun memenuhi kebutuhan rumah tangga sehari-hari.

Pangan, energi dan air adalah sumberdaya sekaligus potensi masalah besar dunia. ${ }^{1}$ Ketahanan pangan, ketahanan energi, dan ketahanan air menjadi perhatian dan agenda pembangunan semua negara. Perserikatan Bangsa- Bangsa, dengan berbagai lembaganya memiliki bermacam inisiatif yang berkaitan dengan ketahanan pangan, ketahanan energi, dan ketahanan air. Tujuan Pembangunan Berkelanjutan (Sustainable Development Goals) mengagendakan pangan, energi dan air untuk ditingkatkan ketersediaan, keterjangkauan dan mutunya di seluruh belahan dunia.

Ketahanan pangan, ketahanan energi, dan ketahanan air bukanlah masalah yang berdiri sendiri-sendiri. Sebaliknya, mereka terkait sangat erat satu sama lain, yang sering diungkapkan belakangan sebagai "food-energy- water" (FEW) nexus. Sebagai contoh, program ketahanan pangan akan membutuhkan air dalam jumlah besar, yang dapat disiapkan antara lain melalui pembangunan jaringan irigasi. Demikian pula program peningkatan ketahanan energi mungkin membutuhkan air dalam skala besar untuk menggerakkan turbin pembangkit listrik, atau membutuhkan biomass maupun komoditas pertanian lainnya yang akan memiliki pengaruh pada pencapaian program ketahanan pangan.

Meskipun permasalahan ketahanan pangan, ketahanan energi, dan ketahanan air merupakan masalah yang relatif sudah lama dihadapi berbagai negara, namun riset untuk mempelajari permasalahan keterkaitan antara ketahanan pangan, ketahanan energi dan ketahanan air relatif belum lama dilakukan, baru sejak awal 2010-an (Simpson \& Jewitt, 2019; Endo et. al, 2015). Hubungan antara ketiganya dapat bersifat sinergi, konflik, maupun trade-off, dan bersifat dinamik. Karena keterkaitan tersebut sangat penting untuk dipahami, juga dengan meningkatnya perhatian dunia terhadap permasalahan perubahan iklim (climate change) dan kemudian pembangunan keberlanjutan (sustainable development), maka riset dan inisiatif yang berkaitan dengan food-energy-water (few) nexus berkembang pesat belakangan.

Tahun 2020 dimulai program-program pembangunan dalam kerangka Rencana Pembangunan Jangka Menengah Nasional (RPJMN) 2020-2024. Permasalahan ketahanan pangan, ketahanan energi, serta ketahanan air, sebagaimana dalam RPJMN sebelumnya (misalnya RPJMN 2014-2019) tetap menjadi prioritas untuk dihadapi permasalahannya/ dilakukan pembangunannya. Namun demikian, kegiatan dalam program ketahanan pangan, ketahanan energi, serta ketahanan air,
${ }^{1}$ Dikemukakan misalnya oleh Sekjen PBB Ban-Ki Moon dalam World Water Day 2011. https://archive.worldwaterday.org/2011/about.html 
khususnya dalam tahun pertama Rencana Kerja Pemerintah (RKP 2020) masih nampak berdiri sendiri-sendiri, belum memperlihatkan keterkaitan yang kuat di antara ketiganya.

Makalah ini mengusulkan agar keterkaitan (nexus) antara ketahanan pangan, ketahanan energi, serta ketahanan air dapat ditingkatkan dan secara eksplisit diperlihatkan, khususnya dalam RKP tahun-tahun berikutnya dalam kurun RPJMN 2020-2024. Hal ini didapat dengan mempelajari pustaka terutama mengenai food-energy-water nexus serta naskah Rencana Pembangunan Jangka Menengah Pembangunan Nasional 2020-2024 dan periode sebelumnya.

\section{Keterkaitan antara ketahanan pangan, energi, dan air}

Di dalam Tujuan Pembangunan Berkelanjutan, yang juga diacu oleh RPJMN 2020-2024, ketahanan pangan memiliki kaitan yang kuat dan langsung dengan pencapaian tujuan nomer 1, 2, 3, dan 15. Demikian pula, ketahanan energi, terutama yang berbasis energi terbarukan, akan menyumbangkan peranan penting dalam pencapaian tujuan nomer 7, 11, dan 13. Sementara itu, ketahanan air memiliki peranan yang penting dalam pencapaian langsung tujuan nomer 1, 2, 3, 6, dan 14 . Sesungguhnya di antara berbagai tujuan dalam Tujuan Pembangunan Berkelanjutan tersebut terdapat hubungan yang erat, baik secara langsung maupun tidak langgsung. ${ }^{2}$

Dengan penelaahan lebih lanjut dapat ditemukan bahwa ketahanan pangan, ketahanan energi dan ketahanan air tidak saja membentuk nexus yang kuat di antara mereka, namun juga dengan sektor-sektor sumber daya alam lainnya, khususnya hutan dan lingkungan. Hal ini dapat diilustrasikan sebagaimana pada Gambar 1.

Besarnya keterkaitan sedapat mungkin disajikan dalam angka. Di dalam Tabel 1 . ditunjukkan gambaran mengenai besarnya kaitan antara air, pangan, dan energi yang dirangkum dari berbagai sumber, khususnya lembaga internasional dalam laporan/publikasi yang terdapat terutama dalam situs Web mereka.

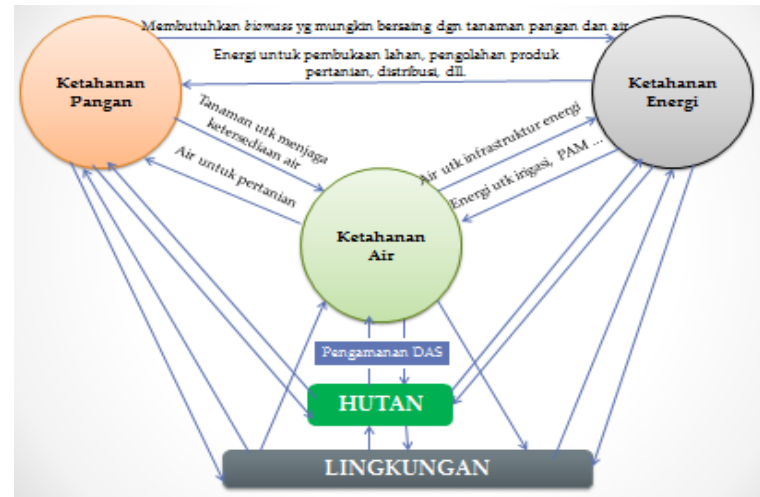

Gambar 1. Ilustrasi keterkaitan (nexus) antara ketahanan pangan, ketahanan energi, dan ketahanan air

Tabel 1. Perkiraan besaran keterkaitan antara air, pangan, dan energi

\begin{tabular}{|c|l|c|}
\hline No. & \multicolumn{1}{|c|}{ Perkiraan besaran keterkaitan } & \multicolumn{1}{|c|}{ Sumber } \\
\hline 1 & Pertanian menghabiskan sekitar 70\% konsumsi air dunia. & FAO, UN Water \\
\hline 2 & $\begin{array}{l}\text { Sekitar 75\% dari penggunaan air di industri adalah untuk } \\
\text { produksi energi. }\end{array}$ & UNESCO (2014) \\
\hline 3 & $\begin{array}{l}\text { Produksi dan rantai pasok makanan menggunakan sekitar 30\% } \\
\text { konsumsi energi global. }\end{array}$ & UNESCO (2012) \\
\hline 4 & $90 \%$ dari produksi listrik dunia sangat membutuhkan air. & UNESCO (2014) \\
\hline
\end{tabular}




\begin{tabular}{|c|c|c|}
\hline 5 & $\begin{array}{l}\text { Permintaan air global diproyeksikan meningkat sebesar } 55 \% \\
\text { pada tahun } 2050 \text {, terutama karena meningkatnya permintaan } \\
\text { dari industri }(400 \%) \text {. Pada tahun } 20250 \text {, lebih dari } 40 \% \text { penduduk } \\
\text { bumi diproyeksikan tinggal di daerah yang mengalami } \\
\text { kelangkaan air parah. }\end{array}$ & UNESCO (2014) \\
\hline 6 & $\begin{array}{l}\text { Pendinginan pembangkit listrik menggunakan } 43 \% \text { dari } \\
\text { penarikan air segar di Eropa (lebih dari } 50 \% \text { di beberapa negara), } \\
\text { hampir } 50 \% \text { di Amerika Serikat, dan lebih dari } 10 \% \text { "water } \\
\text { cap"nasional di Cina. }\end{array}$ & UNESCO (2014) \\
\hline 7 & $\begin{array}{l}\text { Pada tahun } 2035 \text {, penarikan air untuk produksi energi akan } \\
\text { meningkat sekitar } 20 \% \text { dan konsumsinya sebesar } 85 \% \text {, didorong } \\
\text { perkembangan pembangkit listrik dengan efisiensi yang lebih } \\
\text { tinggi dan sistem pendingin yang lebih baik, dan peningkatan } \\
\text { produksi biofuel. }\end{array}$ & UNESCO (2014) \\
\hline 8 & $\begin{array}{l}\text { Persediaan air tanah semakin menipis, sekitar } 20 \% \text { dari akuifer } \\
\text { dunia dieksploitasi secara berlebihan. Kerusakan lahan basah di } \\
\text { seluruh dunia mengurangi kapasitas ekosistem untuk } \\
\text { memurnikan air. }\end{array}$ & UNESCO (2014) \\
\hline 9 & $\begin{array}{l}\text { Dibutuhkan } 3.000-5.000 \text { liter air untuk menghasilkan } 1 \mathrm{~kg} \\
\text { beras, } 2.000 \text { liter untuk menghasilkan } 1 \mathrm{~kg} \text { kedele, } 900 \text { liter untuk } \\
1 \mathrm{~kg} \text { gandum, dan } 500 \text { liter untuk } 1 \mathrm{~kg} \text { kentang. }\end{array}$ & WWF \\
\hline
\end{tabular}

Keterkaitan (nexus) antara pangan, energi dan air dan akan sangat penting untuk dikaji lebih dalam dan dirumuskan program-program pembangunannya. Hal ini sangat relevan untuk Indonesia mengingat karakteristiknya sebagai negara kepulauan, dengan ketersediaan dan permintaan akan pangan, energi, dan air yang berbeda-beda antar pulau, serta kesiapan prasarananya yang juga bervariasi sangat besar. Struktur ekonomi, karakteristik penduduk dan geografi yang beragam serta pola pendapatan dan pengeluaran yang berbeda-beda antar pulau dan wilayah/region, termasuk misalnya antar kawasan Indonesia Timur dan Barat membentuk nexus pangan, energi dan air (few nexus) yang unik untuk Indonesia.

\section{III. “FEW Nexus” dalam RPJMN 2014-2019}

RPJMN 2014-2019 telah memasukkan Ketahanan Air, Ketahanan Pangan, dan Ketahanan Energi dalam Program Prioritas.
Namun demikian, bagaimana hubungan/keterkaitan yang diperkirakan terjadi antara ketiga program "Ketahanan" tersebut, baik sebagai sinergi atau dalam bentuk yang merugikan belum diungkapkan dengan cukup mendalam. Dengan perkataan lain, ketiga program ketahanan tersebut diasumsikan dapat dilakukan secara secara sendiri-sendiri, tanpa atau hanya dengan sedikit membutuhkan dukungan kordinasi di antara sektor pangan, energi, dan air.

Di dalam program ketahanan pangan misalnya, disebutkan sasaran program dalam bentuk asupan kalori yang hendak dituju, pembukaan lahan pertanian hingga rencana peningkatan produksi beberapa komoditas pertanian, ternak maupun perikanan. Namun demikian sasaran program ketahanan pangan tersebut tidak/belum menunjukkan perhitungan kebutuhan air maupun energi yang diperlukan, 
maupun dampak dari pembangunan ketahanan pangan tersebut kepada sektor energi dan air.

Demikian pula dalam program ketahanan energi disebutkan bahwa rasio elektrifikasi mendekati 100 persen akan diupayakan tercapai; disebutkan pula peningkatan dan sasaran pembangunan energi terbarukan. Namun berapa besar volume air maupun banyaknya dan jenis tanaman pangan yang mungkin digunakan dalam program ketahanan energi belum dirinci. Juga dampak dari pembangunan energi tersebut untuk memperkokoh ketahanan pangan maupun air. Hal serupa ditemukan pula pada program ketahanan air, dimana sasaran program ketahanan air belum/tidak memperhitungkan kebutuhan energi maupun tanaman pangan yang mungkin digunakan, maupun dampak program ketahanan air terhadap ketahanan pangan dan ketahanan energi.

Di dalam RPJMN 2020-2024 diperkenalkan program pembangunan berupa sejumlah Major Project, suatu hal yang belum dijumpai dalam dokumen RPJMN sebelumnya. ${ }^{1}$ Di antara 41 major project yang tercantum, sebagai contoh, terdapat major project yang memperlihatkan keterkaitan antara ketahanan energi dan ketahanan pangan, yaitu "Pembangunan Energi Terbarukan Green Fuel Berbasis Kelapa Sawit”. Di dalam major project yang bertujuan meningkatkan pangsa energi terbarukan dalam bauran konsumsi energi Indonesia serta menekan defisit neraca pembayaran karena besarnya impor BBM, disebutkan bahwa akan dibutuhkan bahan baku berupa CPO (crude palm oil) dari perkebunan kelapa sawit di dalam negeri. Namun bagaimana dampak permintaan CPO untuk diubah menjadi green fuel tersebut terhadap pemanfaatan minyak sawit untuk bahan makanan belum jelas diungkapkan. Demikian pula kemudian dampak dari penambahan luas perkebunan kelapa sawit untuk memenuhi permintaan sebagai bahan baku green fuel terhadap penyerapan air di wilayah sekitar perkebunan.

Contoh lain adalah major project "9 Kawasan Industri di luar Jawa dan 31 Smelter". Program industrialisasi skala besar, yang diharapkan memberikan dampak pertumbuhan ekonomi cukup besar di sekitar wilayah pembangunan industri tersebut dipastikan akan membutuhkan energi dan air yang cukup besar. Bagaimanakah kebutuhan air serta energi tersebut akan berpengaruh terhadap penyediaan pangan di sekitar wilayah pembangunan proyek industri/smelter tersebut nantinya? Hal demikian akan menarik dan sangat penting apabila dikemukakan lebih rinci.

Selain itu masih terdapat beberapa permasalahan/tantangan lain yang tidak cukup tegas disebutkan dari program-program ketahanan pangan, ketahanan energi, dan ketahanan air dalam dokumen RPJMN 20202014, atau permasalahan yang masih dihadapi bersama. Pertama, yang menyangkut isu keberlanjutan (sustainability). Eksploitasi terhadap pangan, energi dan air yang dilakukan oleh berbagai sektor ekonomi belum jelas mengungkapkan keterbatasan dari sumberdaya di dalam negeri (indigenous resources) akan pangan, energi, maupun air. Bagaimana skenario pemenuhan kebutuhan akan pangan, energi maupun air yang diproyeksikan meningkat tersebut belum dirancangkan dengan rinci. Lebih jauh dampak terhadap perubahan iklim serta pembangunan berkelanjutan belum diungkapkan.

Kedua, masalah pengelola dan level kewenangan. Kewenangan pengelolaan masalah pangan, energi, dan air terbagi tidak merata antara pemerintah pusat, propinsi, dan

${ }^{1}$ Peraturan Presiden No. 18 Tahun 2020 tentang Rencana Pembangunan Jangka Menengah Nasional Tahun 20202024, Lampiran 2. 
kabupaten. Sasaran program ketahanan pangan, energi dan air dalam RPJMN 2020-2025 masih berada dalam tataran makro, belum merinci bagaimana pencapaian sasaran tersebut didelegasikan antar pemegang kewenangan; hal ini mungkin berakibat sulitnya mewujudkan sasaran pembangunan nasional. Isu pengelola dan kewenangan ini akan semakin penting untuk dijawab khususnya setelah diterbitkannya kerangka regulasi baru, misalnya UndangUndang (UU) mengenai Pemerintah Daerah dan UU mengenai Desa.

Ketiga, bagaimana sinergi antar ketiga program tersebut (ketahanan pangan, ketahanan energi, ketahanan air) dan terkait dengan sumberdaya alam lainnya (hutan) serta lingkungan hidup belum diidentifikasikan dengan jelas. Program pembangunan untuk memperkuat hubungan antar sektor untuk mempermudah pencapaian sasaran masingmasing sektor belum disebutkan secara tegas.

\section{Kesimpulan dan rekomendasi}

Pangan, energi, dan air adalah kebutuhan dasar manusia dan ketiganya membentuk hubungan yang sangat erat (nexus). Namun selain sebagai sumber kehidupan utama manusia, pangan, enegi, dan air juga berpotensi menjadi sumber masalah/konflik, baik di dalam negeri maupun antar negara. Perhatian terhadap hubungan antara pangan, energi, dan air telah berkembang belakangan terutama terkait dengan permasalahan pembangunan berkelanjutan (sustainable development) dan berbagai riset telah berkembang mengenai food, energy, and water nexus.

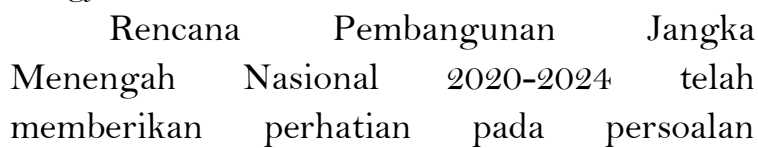
ketahanan pangan, ketahanan energi, dan ketahanan air, namun belum menekankan keterkaitan yang erat antara ketiganya. Keterkaitan antara pangan, energi dan air di Indonesia dengan sifatnya yang mengandung keanekaragaman (diversity) yang sangat tinggi akan bersifat unik, dan perlu dikaji lebih mendalam.

Makalah ini merekomendasikan agar dalam kurun RPJMN 2020-2024 ini dikaji secara mendalam keterkaitan antara ketahanan pangan, ketahanan energi dan ketahanan air termasuk yang telah dirumuskan dalam dokumen Perencanaan Pembangunan Nasional sebelumnya. Dari kajian tersebut diupayakan dihasilkan kebijakan (policy) yang komprehensif mengenai keterkaitan ketahanan pangan, ketahanan energi dan ketahanan air Indonesia, yang kemudian diurai untuk berbagai daerah di Tanah Air. Selanjutnya dari kajian tersebut dan kebijakan yang disusun, dapat dikembangkan program pembangunan mengenai keterkaitan ketahanan pangan, ketahanan energi, dan ketahanan air, untuk mulai dapat diterapkan dalam Rencana Kerja Pemerintah (RKP) dalam kurun RPJMN 2020-2024.

\section{Daftar Pustaka}

Brower, F. et. al. (2018). Energy modelling and the Nexus concept. Energy Strategy Reviews, 19, 1-6.

Endoa, A. et. al. (2017). A review of the current state of research on the water, energy, and food nexus. Journal of Hydrology: Regional Studies, 11, 20-30.

Simpson, G. \& Jewitt, G. (2019). The development of the Water-EnergyFood Nexus as a framework for achieving resource security: A review. Frontiers in Environmental Science, 7, 1-9. 